\title{
MATHEMATICAL MODEL FOR IDENTIFYING AND QUANTIFYING THE OVERALL ENVIRONMENTAL COST
}

\author{
Sorinel CAPUSNEANUD1, Dan Ioan TOPOR ${ }^{(D 2}{ }^{2}$, Mihaela STEFAN HINT ${ }^{(1)}$, \\ Constantin Aurelian IONESCU (D) ${ }^{*}$, Mihaela Denisa COMAN (D) 5 , Liliana PASCHIA (D)4, \\ Nicoleta Luminita GUDANESCU NICOLAU D6 ${ }^{2}$ Oana Raluca IVAN (D2 \\ ${ }^{1}$ Department of Accounting, Faculty of Finance-Banking, Accounting and Business Administration, \\ Titu Maiorescu University, Bucharest, Romania \\ ${ }^{2}$ Department of Finance-Accounting, Faculty of Economic Sciences, 1 Decembrie 1918 University, \\ Alba Iulia, Romania \\ ${ }^{3} \mathrm{PhD}$ School in Accounting of the Faculty of Economic Sciences, 1 Decembrie 1918 University, \\ Alba Iulia, Romania \\ ${ }^{4}$ Faculty of Economics, Hyperion University of Bucharest, Bucharest, Romania \\ ${ }^{5}$ Institute of Multidisciplinary Research for Science and Technology, \\ Valahia University of Targoviste, Targoviste, Romania \\ ${ }^{6}$ Romanian Academy, Institute of National Economy, Bucharest, Romania
}

Received 20 November 2019; accepted 19 March 2020

\begin{abstract}
The paper deals with the environmental costs (EC) in the electrical equipment industry by using environmental accounting as a strategic instrument for controlling the economic entity (EE). The novelty of the study consists of integrating a mathematical model in environmental management accounting (EMA), starting from the identification of the types of waste generated by the production flow and the interaction between the production activity and the environment, which results in determining the EC per entity. The research also analyzes the dependence between the resulting waste and the volume of production by categories. The usefulness of determining these dependencies leads to the identification of the product categories with a significant influence on the EC. The study is useful for developing an environmentally sustainable accounting system within entities in the electrical equipment industry because based on the mathematical model, products that generate large quantities of waste can be identified, allowing the outline of managerial strategies to reviewing production technologies, in order to optimize the products and reduce the quantities of waste generated.
\end{abstract}

Keywords: EMA, environmental costs, mathematical model, electronics, electrical waste, aluminium waste.

JEL Classification: C60, D24, Q53, Q56.

${ }^{\star}$ Corresponding author. E-mail: ionescuaurelian89@gmail.com 


\section{Introduction}

In line with increasingly stringent environmental regulations, industrial costs for environmental protection have increased rapidly over the past 40 years (Gerasimova \& Silka, 2019; Gray, 2010; Jasch, 2003). Conceptual approaches to EC have been of particular importance to both specialists and environmental regulators (Andersen, 2007; Baumann \& Cowell, 1999; Ciambrone, 2018; Nistor et al., 2015; Sauvé et al., 2016; Schaltegger \& Burritt, 2017). Thus, EC represent costs that business incur for their customers in order to produce goods and services (U.S. Environmental Protection Agency [US EPA], 1995). According to GHG (United Nations, 1997), EC are costs related to actual or potential deterioration of natural assets via economic activities. These costs can be addressed as costs caused by actual challenges or environmental damage through an EE's own activities or, as costs incurred by the EE, regardless of whether they caused the damage (Everett et al., 2010; Harris \& Codur, 2004; Rakos \& Antohe, 2014).

A clear distinction between the EC and the other costs of an EE is drawn by the Recommendation 453/2001 of the European Commission. Thus, EC are those costs of the actions taken by an EE and by third parties on behalf of an EE for preventing, reducing or repairing the environmental damage resulting from operational activities. These costs include: storage and disposal of waste, soil protection, ground and surface water protection, clean air and climate protection, noise reduction, biodiversity, and landscape protection (European Commission, 2001). Another global body believes that these "include the costs of the measures that should be taken, in order to manage the environmental impact of a company's activity, in an environmentally responsible manner, as well as other costs determined by the environmental goals and requirements of the enterprise" (United Nations Conference on Trade and Development [UNCTAD], 2001). Seeing the approaches above, it can be affirmed that, the EC can be those costs borne directly or indirectly by an EE in order to prevent, reduce or repair certain damages caused to the environment as a result of its activities. Therefore, EC may include but are not limited to: waste disposal, soil, air, ground and surface water protection, noise pollution reduction, biodiversity and landscape protection (Grubb et al., 2019; Ionescu, 2017).

The electrical and electronic equipment industry was given increased attention both by the authorities, from a legislative, as well as from various researchers' point of view, attention mainly due to the increase of waste resulting from these activities (da Cruz et al., 2014; Mazahir et al., 2019). Various studies have been carried out to identify the possibilities of minimizing and eliminating waste from electrical and electronic equipment manufacturing activities (Kusch-Brandt, 2018; Lauridsen \& Jørgensen, 2010). An EE producing electrical appliances was chosen for the study carried out, motivated by the global accentuated development of the electrical and electronic equipment industry.

In the research carried out, the identification of the types of waste generated from the production flow of the analysed EE, as well as the identification of the interaction between the production activity and the environment, led to the creation of a mathematical model to determine the total EC per entity. The study continued by investigating the dependence between the resultant waste and the volume of production by categories, an analysis that 
required a hierarchy of product types according to the weight of the total production of the EE. Thus, a model was created to determine the dependence between the aluminium wastes $(A l w)$. The model created is intended to be useful in identifying those product categories that affect the EC most. The utility of the generated model resides in the possibility of its application and implementation for various production entities. Results of estimations of the overall environment cost disclose the difference between the actual and calculated value of the waste and the necessity of more accurate accounting of the environmental cost. The structure of the research presents the main studies from the scientific literature, the applied materials and methods, followed by the results, discussions and conclusions of the research.

\section{Literature review}

Accounting systems traditionally attribute many of the EC to overall costs (which are not directly allocable), as a result of which production managers are not stimulated to reduce EC and are not directly aware of the extent of these costs (Gale, 2006; Jasch, 2009; Tsui, 2014). By identifying, evaluating and allocating EC, managers are allowed to identify cost-saving opportunities for creating a clean production system (Burritt et al., 2019; Sorina-Geanina et al., 2012) to be applied to the entire production cycle in order to increase productivity by: i) ensuring the efficient use of raw materials, energy and water, and generally non-renewable resources; ii) reduction, at the source, of waste and emissions; iii) reducing the impact of products on the environment, during their life cycle, by designing environmentally friendly and cost-effective products (Bebbington \& Larrinaga, 2014; Jasch, 2009; Zou et al., 2019). Hroncová Vicianová et al. (2017) consider that it is necessary to set up a separate environmental department within the EE, which will monitor the environmental issues and contribute to the improvement of the environmental performance. The attitude and personal values of the managers towards the environmental aspects lead to the development of a behavior of the entities based on a system of pro-environmental values in order to promote corporate environmental responsibility (Potocan, et al., 2016; Smaliukiene், 2007).

Henri, Boiral, and Roy (2016) pointed out that EC tracking reflects executive (management, control, and cost optimization aspects for business and environmental strategy) and structural (through their influence on the EE's cost structure, especially regarding product design, raw materials used and operational cost), representing an important executive cost management tool that helps align resources and cost structure associated with short-term tactics to reduce costs. Fuzi, Habidin, Janudin, and Ong (2019) examined the relationship between accounting practices of environmental administration, environmental management system and environmental performance, emphasizing that implementing the environmental management system in the industry can help the EE in managing, measuring and improving the environmental management of operations. Ghaemmaghami, Zamani, and Shafiei (2018) highlighted the role of environmental accounting in reducing costs, indicating that its use leads to reducing the level of energy consumption in the production sector, and to reducing waste in this sector.

Determining the total EC per EE is a complex process integrated in the environmental management of the entities, it simultaneously depends on the industry specificity, the size 
of the EE (Armas-Cruz et al., 2017), the production flow and relationships with third parties (Christ \& Burritt, 2013; Lee, 2011). At the same time, the determining elements for the EC can result from various business processes that have a direct or indirect influence on the natural environment (Baldarelli et al., 2017). EE that have implemented environmental management systems support the institutionalization of environmental accounting as an integral part of managerial accounting through the use of quantification methods such as: Activity-Based Costing/Activity-Based Management, Total Quality Management/Total Quality Environmental Management, Design for Environment/Life-Cycle Costing, Business Process, Re-Engineering Cost of Quality Model/Cost of Environmental Quality Model (US EPA, 2014). Also, the implementation of solutions for organic production, through investments in organic technology in order to adjust or modify the production processes and products can contribute to the significant reduction or elimination of the total EC per EE (by Oliveira Neto et al., 2016; Topor et al., 2017), but also to increases in the productivity for the adopting EE (Hottenrott et al., 2016; Mazahrih, 2019). To this end, identifying the categories of products producing a significant contribution of waste, by categories of waste, requires a review of the technology used to manufacture products from those categories, at those points of manufacture where the raw material is used, for the material not to be lost unjustifiably in waste (Kusch-Brandt, 2018).

Determining the dependency relation between a certain type of waste and the categories of manufactured products is of particular importance for the implementation of a sustainable management system at the level of any EE, since: i) it leads to estimation of the volume of waste produced according to the planned volume of production by product categories; ii) analyses of the production technologies can be performed to identify those product categories that generate higher volumes of waste. Thus, the topic of waste in cost accounting, respectively, environmental accounting, deserves special attention. The scientific community agrees that an efficient waste management can allow obtaining economic, environmental and social benefits (Cucchiella et al., 2014), so in the specialized literature, there are numerous studies regarding various aspects of sustainable waste management (Gala et al., 2015). Iriarte has quantified and compared, by evaluating the life cycle, the potential impact that the various systems of the selective municipal waste collection can have on the environment (Iriarte et al., 2009). Rigamonti applied the life cycle assessment methodology for packaging waste management operations and compared the results of the selective collection for the packaging waste surplus (Rigamonti et al., 2009). Ferreira has modeled a real packaging waste recycling system by assessing the environmental impact based on the life cycle assessment of a product (Ferreira et al., 2014).

\section{Materials and methods}

\subsection{Materials}

The activity of an EE dealing with production in the field of electrical appliances will interact with the environment in different ways, at different technological flow stages. The interaction between production activity and environment, at such an EE, can be represented 
schematically according to Figure 1 . In the EE under analysis, it results in a series of wastes at different times of the activities, namely: from unpacking raw material usually packed in cardboard or plastic bags; from processing related to the production processes (ferrous or non-ferrous scrap, pieces of plastic or glass; by packing the products before delivery (scraps of paper, cardboard or plastics). These wastes are transferred to Dozal Plast, which deals with the recovery. In exchange, the EE is paid, the price depending on the nature of the waste collected for recovery.

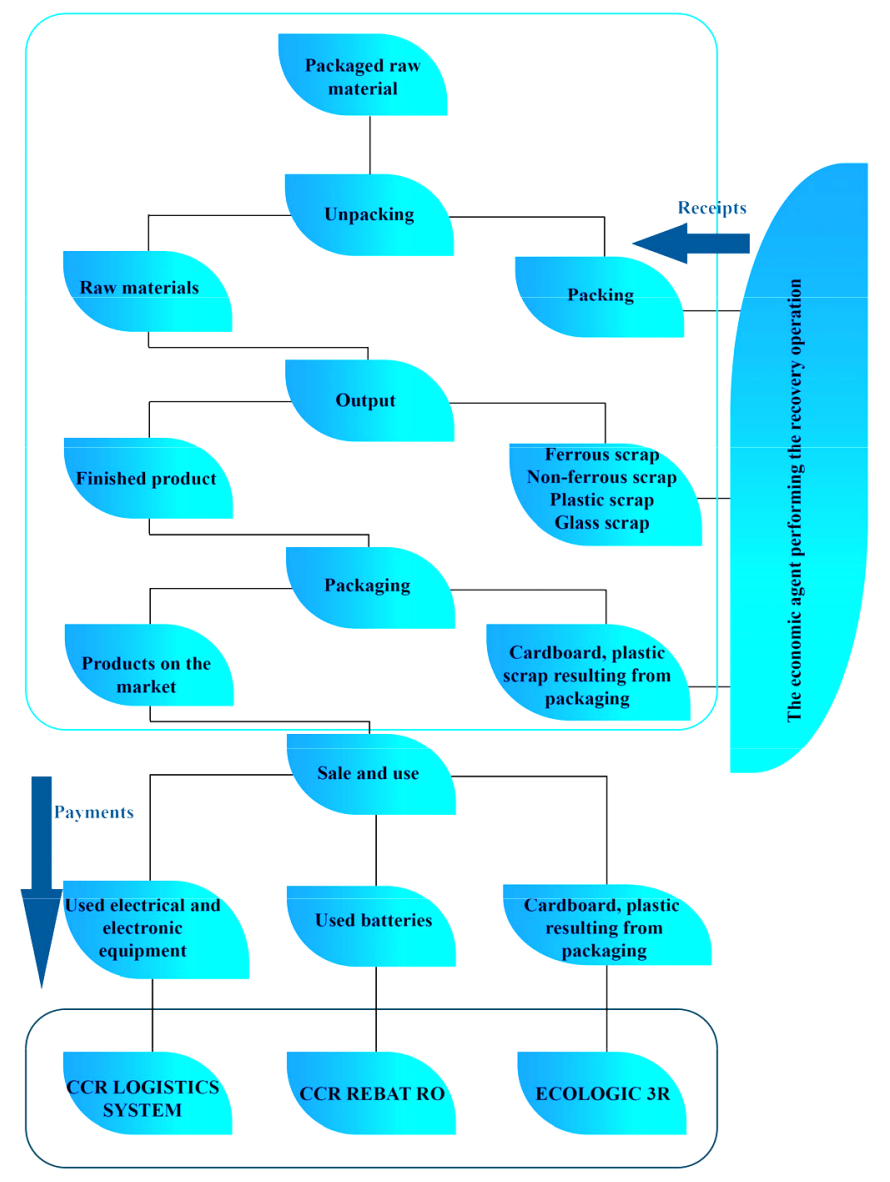

Figure 1 . The interaction between the production activity and the environment

However, the EC of the EE are affected by another aspect, namely that the EE puts on the market products that affect the environment. For this reason, the entity must pay taxes in three directions, each tax being to offset a certain aspect of its environmental degradation, to contribute to the payment of works to prevent environmental degradation. The three important directions envisaged for the prevention of environmental problems are: i) avoiding environmental pollution by throwing away used electrical appliances, for which purpose the manufacturer of electrical appliances pays a tax to CCR Logistic System, to be used to reha- 
bilitate the degraded environment by throwing away electrical equipment and appliances; ii) avoiding environmental pollution by discarding used batteries, for which the manufacturer of electrical appliances (which also contain batteries) pays a fee to CCR Rebat. The fee will be used to rehabilitate the environment degraded by used batteries; iii) avoiding environmental pollution by throwing away packaging (paper, cardboard, plastic), which is why, for packaged products placed on the market, the EE pays taxes to Ecological 3R.

Since the fee paid to CCR Logistic is proportional to the weight of the production (the aggregate weight of all the devices placed on the market), the EE makes a monthly declaration containing the information regarding all the products placed on the market, with quantities delivered, weight in kilograms of each of them, and the total weight of each product. Table 1 contains an example calculating the mass of equipment delivered in April 2018.

Table 1. Calculation model for a monthly declaration to CCR Logistic

\begin{tabular}{|c|c|c|c|}
\hline Product type & $\begin{array}{c}\text { Product weight } \\
{[\mathrm{kg}]}\end{array}$ & $\begin{array}{l}\text { Products delivered } \\
\text { [pcs] }\end{array}$ & $\begin{array}{l}\text { Quantity delivered } \\
{[\mathrm{kg}]}\end{array}$ \\
\hline Beacon type_A & 0.80 & 103 & 82.40 \\
\hline Beacon type_C & 6.00 & 1 & 6.00 \\
\hline 24_LED_linear_projector & 2.50 & 4 & 10.00 \\
\hline Atlas_of_3LEDs & 0.40 & 1 & 0.40 \\
\hline Atlas_of_5LEDs & 0.90 & 1 & 0.90 \\
\hline Atlas_of_24LEDs & 2.00 & 83 & 166.00 \\
\hline CISA_LS05 & 0.87 & 4 & 3.50 \\
\hline Ceiling_light_Slim_Display_II & 3.00 & 57 & 171.00 \\
\hline SS_Solar & 1.60 & 3 & 4.80 \\
\hline Photon_SP_II_10LEDs & 1.30 & 140 & 182.00 \\
\hline Photon_SP_II_12LEDs & 1.75 & 31 & 54.30 \\
\hline Photon_SP_II_18LEDs & 2.00 & 56 & 112.00 \\
\hline Photon_SP_II_24LEDs & 3.48 & 9 & 31.30 \\
\hline Photon_SP_II_72LEDs & 7.60 & 6 & 45.60 \\
\hline Apolo_hall_projector & 3.80 & 3 & 11.40 \\
\hline APOLO_II_2cobs & 4.52 & 156 & 705.10 \\
\hline APOLO_II_3cobs & 6.00 & 32 & 192.00 \\
\hline APOLO_II_4cobs & 7.45 & 65 & 484.30 \\
\hline APOLO_II_6cobs & 12.00 & 8 & 96.00 \\
\hline Display_Line_III034_5modules & 3.00 & 209 & 627.00 \\
\hline Linea_rod & 0.40 & 2 & 0.80 \\
\hline Reloc_corner & 0.50 & 4 & 2.00 \\
\hline Leon_035_4 modules & 1.00 & 3 & 3.00 \\
\hline TOTAL & & 981 & $2,992.00$ \\
\hline
\end{tabular}


Also, the fee paid to CCR Rebat is proportional to the weight of the batteries placed on the market. The technological processes of electrical appliances manufacturing trigger the production of a series of wastes, which the EE can use, namely: aluminium scrap, cuttings, scrap iron, cardboard, glass, plastic. Since, by contract with Ecologic 3R (the environmental service provider), cardboard and plastic waste are collected by the service provider for free, it means that money is recovered only from the other types of waste (aluminium, aluminium cuttings, iron waste).

\subsection{Methods}

The paper aims to develop a mathematical model that is easy to apply and integrate into EE practice, to determine as accurately as possible the total environmental cost. In order to determine the total EC per EE, it is necessary to determine the EC related to the marketing of electrical products, batteries, and packaging. The calculation of the EC via the placing on the market of electrical products (CLOGI), cost to be paid to CCR Logistic is performed according to the following formula:

$$
C^{L O G I}=c^{\text {prod }} \sum_{i=1}^{n} p_{i} w_{i},
$$

where: $n$ - number of types of products produced by the EE, $w_{\mathrm{i}}$ - weight of product $i$ in kilograms, $p_{i}$ - number of items of product $i$, delivered in a month, and $c^{\text {prod }}$ - average cost per kilogram of product delivered to the market.

Determining the average cost per product $c^{\text {prod: }}$

$$
c^{\text {prod }}=\frac{T p^{L O G I}}{T w e},
$$

where: $T p$ - total amounts paid to CCR Logistic, and Twe - total weight of equipment placed on the market.

Since the fee paid to CCR Rebat is proportional to the weight of the batteries placed on the market, using a reasoning similar to the one presented above, the average cost per $1 \mathrm{~kg}$ of batteries delivered on the market can be calculated using the relation:

$$
C^{R E B A T}=c^{b a t} w_{b},
$$

where: $w_{b}$ - the weight of the batteries placed on the market in one month, and $c^{b a t}$ - average cost per kilogram of batteries placed on the market, calculated according to the following relation:

$$
c^{b a t}=\frac{T b^{R E B A T}}{T w b},
$$

where: $T b^{R E B A T}$ - total amounts paid to CCR Rebat, and Twb - total weight batteries and accumulators placed on the market.

The following formula, based on the weight of the packages placed on the market, represents the amount owed to Ecological 3R:

$$
C^{E C O L}=c^{\text {pack }} w_{p},
$$

where: $w_{p}$ - weight of packages placed on the market in the respective month expressed in 
kilograms and $c^{\text {pack }}$ - average cost paid per kilogram of packaging placed on the market, calculated according to the following formula:

$$
c^{\text {pack }}=\frac{T p a c k^{E C O L}}{T w_{\text {pack }}},
$$

where: $T p a c k E C O L$ - total amounts paid to Ecological 3R, and $T w_{\text {pack }}$ - total weight of packaging placed on the market.

The total EC per unit is determined by summing the costs determined previously:

$$
C=C^{L O G I}+C^{R E B A T}+C^{E C O L} \text {. }
$$

This calculation can be detailed in a form that shows the dependence of the cost on the number of items of each product manufactured, packaged, and placed on the market monthly. In a matrix form, this dependence is expressed as follows:

$$
C=\left(\begin{array}{lllll}
p_{1} & p_{2} & \cdots & p_{n} & 1
\end{array}\right)\left[\begin{array}{ccc}
w_{1} & 0 & 0 \\
w_{2} & 0 & 0 \\
\cdots & \cdots & \cdots \\
w_{n} & 0 & 0 \\
0 & w_{b} & w_{p}
\end{array}\right]\left[\begin{array}{c}
c^{\text {prod }} \\
c^{\text {bat }} \\
c^{\text {pack }}
\end{array}\right] .
$$

Seeing the recovered values, the relationship that expresses the EC becomes:

$$
C=\left(\begin{array}{lllll}
p_{1} & p_{2} & \cdots & p_{n} & 1
\end{array}\right)\left[\begin{array}{ccc}
w_{1} & 0 & 0 \\
w_{2} & 0 & 0 \\
\cdots & \cdots & \cdots \\
w_{n} & 0 & 0 \\
0 & w_{b} & w_{p}
\end{array}\right]\left[\begin{array}{c}
c^{\text {prod }} \\
c^{\text {bat }} \\
c^{\text {pack }}
\end{array}\right]-I_{1}-I_{2}-I_{3},
$$

where: $I_{1}$ - revenues received from the recovery of type 1 waste (aluminium), $I_{2}$ - revenues collected from the recovery of type 2 waste (aluminium cuttings), and $I_{3}$ - revenues collected from the recovery of type 3 waste (iron scrap).

It is important to analyze which products incur such waste. It is well known that in the manufacturing process there are products that result in a greater quantity of waste (cuttings), while from other products, the amount of waste is insignificant or even does not result any waste. For example, if a product does not contain aluminium, then aluminium cuttings will not be produced in the manufacturing process due to that product. For this purpose, it would be important to know the function that expresses the dependence between the number of pieces of each manufactured product and the resulting amount of waste. It can be considered 
the case of the Alw expressed by a polynomial function (10) analogously it can be considered a polynomial function for the aluminium scrap (11), respectively, for scrap iron (12).

$$
\begin{aligned}
& I_{1}=f_{1}\left(p_{1}, p_{2}, p_{3} \ldots p_{n}\right)=a_{11} p_{1}+a_{12} p_{2}+a_{13} p_{3}+\ldots+a_{1 n} p_{n} \\
& I_{2}=f_{2}\left(p_{1}, p_{2}, p_{3} \ldots p_{n}\right)=a_{21} p_{1}+a_{22} p_{2}+a_{23} p_{3}+\ldots+a_{2 n} p_{n} \\
& I_{3}=f_{3}\left(p_{1}, p_{2}, p_{3} \ldots p_{n}\right)=a_{31} p_{1}+a_{32} p_{2}+a_{33} p_{3}+\ldots+a_{3 n} p_{n},
\end{aligned}
$$

where: $p_{n}$ - number of pieces made from product $\mathrm{k} ; a_{1 n}$ is a coefficient expressing the participation of a piece of product $k$ in the formation of $A l w ; a_{2 n}$ is a coefficient expressing the participation of a piece of product $k$ in the formation of aluminium cuttings; $a_{3 n}$ is a coefficient expressing the participation of a piece of product $k$ in the formation of scrap iron. If one of the coefficients " $a$ " has a value of zero, it expresses that the respective product does not participate in the formation of the waste. If the value of the coefficient is very small, it means that the product has certain participation in the formation of the waste, but it is negligible. If the value of the coefficient is significant, it means that the participation of the product in the formation of the waste is significant. Thus, in a matrix format, the total of the amounts resulting from the recovery of waste is:

$$
I_{1}+I_{2}+I_{3}=(1,1,1)\left[\begin{array}{cccc}
a_{11} & a_{12} & \ldots & a_{1 n} \\
a_{21} & a_{22} & \ldots & a_{2 n} \\
a_{31} & a_{32} & \ldots & a_{3 n}
\end{array}\right]\left[\begin{array}{c} 
\\
p_{1} \\
p_{2} \\
\ldots \\
p_{n}
\end{array}\right]
$$

The determination of the dependence between the resulting waste and the volume of production by categories consists in fact in determining the coefficients $a_{11}, a_{12}, \ldots, a_{1 n}$, so that, by applying them on the production volume (monthly or over a longer period) of each category $p_{1}, p_{2}, \ldots, p_{n}$ to lead to a result as close as possible to the value of the waste recovered for that period. From a mathematical viewpoint, for type $1-A l w\left(I_{1}\right)$ things can be expressed as follows:

$$
a_{11} p_{1}+a_{12} p_{2}+\ldots+a_{1 n} p_{n}=I_{1} \pm \varepsilon
$$

It was noted with $\varepsilon$ the deviation (difference) between the actual value of the waste $I_{1}$ and the value calculated on the basis of the coefficients of dependence. It is desirable that the value $\varepsilon$ be as small as possible for each time interval of the equation.

\section{Results}

For testing the model, it was used information from a period of 24 months from 2017-2018, regarding the quantity of products, of batteries, respectively, of the packaging (cardboard) placed on the market, as well as the payments made periodically to the three collaborating EE (Table 2). 
Table 2. Categories that generate Waste

\begin{tabular}{|c|c|c|c|c|c|c|c|}
\hline Month & $\begin{array}{l}\text { Electrical } \\
\text { and } \\
\text { electronic } \\
\text { equipment } \\
\text { placed on } \\
\text { the market } \\
{[\mathrm{kg}]}\end{array}$ & $\begin{array}{l}\text { Batteries } \\
\text { and } \\
\text { accumu- } \\
\text { lators } \\
\text { placed on } \\
\text { the market } \\
\text { [kg] }\end{array}$ & $\begin{array}{l}\text { Cardboard, } \\
\text { plastic } \\
\text { placed on } \\
\text { the market } \\
{[\mathrm{kg}]}\end{array}$ & $\begin{array}{l}\text { Amount } \\
\text { paid to } \\
\text { CCR } \\
\text { Logistic } \\
\text { [eur] }\end{array}$ & $\begin{array}{c}\text { Amount } \\
\text { paid to } \\
\text { CCR } \\
\text { Rebat } \\
\text { [eur] }\end{array}$ & $\begin{array}{c}\text { Amount } \\
\text { paid to } \\
\text { Ecologic } \\
3 \mathrm{R} \\
\text { [eur] }\end{array}$ & $\begin{array}{c}\text { Total } \\
\text { amount } \\
\text { paid } \\
\text { [eur] }\end{array}$ \\
\hline 1 & 947.00 & 240.00 & 14.00 & 908.32 & 0.00 & 6.55 & 914.87 \\
\hline 2 & $1,379.00$ & 0.00 & 24.00 & 0.00 & 0.00 & 11.45 & 11.45 \\
\hline 3 & $2,123.00$ & 0.00 & 11.20 & 0.00 & 0.00 & 17.81 & 17.81 \\
\hline 4 & $1,513.00$ & 170.00 & 4.30 & 908.73 & 0.00 & 9.67 & 918.41 \\
\hline 5 & $1,450.00$ & 0.00 & 6.00 & 0.00 & 0.00 & 0.00 & 0.00 \\
\hline 6 & $1,211.00$ & 0.00 & 13.00 & 0.00 & 0.00 & 8.20 & 8.20 \\
\hline 7 & $1,017.00$ & 0.00 & 13.00 & 852.56 & 0.00 & 10.82 & 863.38 \\
\hline 8 & 816.00 & 0.00 & 13.00 & 0.00 & 0.00 & 17.46 & 17.46 \\
\hline 9 & 912.00 & 0.00 & 12.80 & 0.00 & 0.00 & 17.46 & 17.46 \\
\hline 10 & $1,299.00$ & 0.00 & 11.00 & 560.68 & 0.00 & 17.23 & 577.91 \\
\hline 11 & $1,532.00$ & 0.00 & 11.00 & 0.00 & 0.00 & 14.91 & 14.91 \\
\hline 12 & $1,937.00$ & 0.00 & 8.40 & 0.00 & 382.98 & 2.55 & 385.53 \\
\hline 13 & $2,661.00$ & 27.00 & 60.00 & 0.00 & 0.00 & 0.00 & 0.00 \\
\hline 14 & $2,300.00$ & 6.00 & 120.00 & 0.00 & 0.00 & 15.94 & 15.94 \\
\hline 15 & $2,645.00$ & 10.00 & 226.00 & 965.77 & 379.79 & 23.52 & $1,369.08$ \\
\hline 16 & $2,992.00$ & 1.00 & 160.00 & 194.07 & 13.73 & 50.42 & 258.22 \\
\hline 17 & $2,755.00$ & 15.00 & 196.00 & 0.00 & 0.00 & 23.06 & 23.06 \\
\hline 18 & $1,481.00$ & 22.00 & 117.00 & 0.00 & 0.00 & 36.97 & 36.97 \\
\hline 19 & $5,870.00$ & 12.00 & 272.00 & 0.00 & 0.00 & 30.60 & 30.60 \\
\hline 20 & $1,156.00$ & 2.00 & 154.00 & 203.11 & 12.13 & 42.27 & 257.52 \\
\hline 21 & $1,549.00$ & 1.00 & 85.00 & 0.00 & 0.00 & 29.54 & 29.54 \\
\hline 22 & $2,939.00$ & 6.00 & 277.00 & 0.00 & 0.00 & 19.09 & 19.09 \\
\hline 23 & $4,990.00$ & 9.00 & 250.00 & 199.92 & 4.79 & 51.30 & 256.01 \\
\hline 24 & 0.00 & 0.00 & 0.00 & 0.00 & 0.00 & 46.52 & 46.52 \\
\hline TOTAL & $47,474.00$ & 521.00 & $2,058.70$ & $4,793.17$ & 793.41 & 503.32 & $6,089.91$ \\
\hline
\end{tabular}

According to the data in Table 2, the average costs related to the electrical and electronic equipment placed on the market, respectively the average cost for the batteries and accumulators placed on the market, can be calculated as follows:

$$
\begin{gathered}
c^{\text {prod }}=\frac{4,793.17}{47,474.00}=0.10 \mathrm{Eur} / \mathrm{kg} ; \\
c^{\text {bat }}=\frac{793.41}{521.00}=1.52 \mathrm{Eur} / \mathrm{kg} .
\end{gathered}
$$


If regarding the EC caused by the marketing of products and batteries, things are clear, in the sense that these costs depend on the weight of the products, respectively of the batteries placed on the market, in the case of packaging, things are slightly different, as the amounts paid to Ecological 3R depend on several factors, of which the weight of the packaging plays an important role, and its influence is properly reflected in these costs. Ecological 3R, based on the legislation in force, makes the calculations of the amounts owed by the analysed EE, but to see how the EC depend on each product manufactured and placed on the market, it will be approached the problem from a statistical perspective. For a more precise determination of the level of correlation between the two variables (weight of the packages and the amount paid) the Pearson correlation coefficient is calculated:

$$
r=\frac{\sum_{L=1}^{24}\left(x_{L}-\bar{x}\right)\left(y_{L}-\bar{y}\right)}{\sqrt{\sum_{L=1}^{24}\left(x_{L}-\bar{x}\right)^{2} \sum_{L=1}^{24}\left(y_{L}-\bar{y}\right)^{2}}},
$$

where, $x_{L}$ represents the quantity of packaging placed on the market in month $L, y_{L}$ represents the amount paid to Ecological 3R in the month $L, \bar{x}$ represents the average of the $x_{L}$ values for the 24 months taken into account (the years 2017-2018); $\bar{y}$ represents the average of the $y_{L}$ values over the 24 months.

Table 3. Determining the Pearson correlation

\begin{tabular}{|l|l|c|c|}
\hline \multicolumn{2}{|c|}{} & Weight of the packages & Amount paid \\
\hline \multirow{4}{*}{$\begin{array}{l}\text { Weight } \\
\text { of the } \\
\text { packages }\end{array}$} & Pearson Correlation & 1 & $0.532^{* *}$ \\
\cline { 2 - 4 } & Sig. (2-tailed) & & 0.007 \\
\cline { 2 - 4 } & Sum of Squares and Cross-products & 216276.760 & 85079.216 \\
\cline { 2 - 4 } & Covariance & 9403.337 & 3699.096 \\
\cline { 2 - 4 } & $\mathrm{N}$ & 24 & 24 \\
\hline \multirow{4}{*}{$\begin{array}{l}\text { Amount } \\
\text { paid }\end{array}$} & Pearson Correlation & $0.532^{* *}$ & 1 \\
\cline { 2 - 4 } & Sig. (2-tailed) & 0.007 & 118231.564 \\
\cline { 2 - 4 } & Sum of Squares and Cross-products & 85079.216 & 5140.503 \\
\cline { 2 - 4 } & Covariance & 3699.096 & 24 \\
\cline { 2 - 4 } & $\mathrm{N}$ & 24 & \\
\hline
\end{tabular}

Note: ${ }^{*}$ Correlation is significant at the 0.01 level (2-tailed).

By calculating the Pearson correlation coefficient (Table 3) the value of 0.532 was obtained. Upon careful observation of the representation in Figure 2, a difference is observed between the shapes of the two graphs of 1 unit ( 1 month) on the horizontal axis. The gap is explained by the fact that the amount paid (invoiced) in a month takes into account the activity of the EE the previous month. If the amounts paid (invoiced) one-month back are translated to be correlated with the activity of the previous month, then the Pearson correlation coefficient obtained this time is 0.931 (Table 4). 
Table 4. Determining the Pearson correlation

\begin{tabular}{|c|c|c|c|}
\hline & & Weight of the packages & $\begin{array}{l}\text { Amount paid off one } \\
\text { month ago }\end{array}$ \\
\hline \multirow{5}{*}{$\begin{array}{l}\text { Weight } \\
\text { of the } \\
\text { packages }\end{array}$} & Pearson Correlation & 1 & $0.931^{\star *}$ \\
\hline & Sig. (2-tailed) & & 0.000 \\
\hline & Sum of Squares and Cross-products & 216276.760 & 151992.926 \\
\hline & Covariance & 9403.337 & 6608.388 \\
\hline & $\mathrm{N}$ & 24 & 24 \\
\hline \multirow{5}{*}{$\begin{array}{l}\text { Amount } \\
\text { paid } \\
\text { off one } \\
\text { month } \\
\text { ago }\end{array}$} & Pearson Correlation & $0.931^{\star *}$ & 1 \\
\hline & Sig. (2-tailed) & 0.000 & \\
\hline & Sum of Squares and Cross-products & 151992.926 & 123313.774 \\
\hline & Covariance & 6608.388 & 5361.468 \\
\hline & $\mathrm{N}$ & 24 & 24 \\
\hline
\end{tabular}

Note: ${ }^{*}$ Correlation is significant at the 0.01 level (2-tailed).

A correlation coefficient of 0.931 represents a very strong, directly proportional dependence. It means that, for the determination of the EC via the placing of the packages on the market, a formula can be used based on the weight of the packages placed on the market. The result highlights the amount owed to Ecologic 3R.

$$
c^{\text {pack }}=\frac{503.32}{2,058.7}=0.24 \mathrm{Eur} / \mathrm{kg} .
$$

As one can see from Figure 1, there is waste that the EE recovers (aluminium scrap, cuttings, and scrap iron) by the contract concluded with Ecologic 3R (environmental service provider). For the period under analysis, the situation of these wastes and the amounts recovered is presented in Table 5.

Table 5. Waste situation and amounts recovered

\begin{tabular}{|c|c|c|c|c|c|c|c|c|}
\hline \multirow{2}{*}{ Month } & \multirow{2}{*}{$\begin{array}{l}\text { Electrical } \\
\text { and electro- } \\
\text { nic equip- } \\
\text { ment placed } \\
\text { on the } \\
\text { market }[\mathrm{kg}]\end{array}$} & \multicolumn{2}{|c|}{ Alw } & \multicolumn{2}{|c|}{ Alw cuttings } & \multicolumn{2}{|c|}{ Scrap iron waste } & \multirow{2}{*}{$\begin{array}{c}\text { Total } \\
\text { amount } \\
\text { recovered } \\
\text { [Eur] }\end{array}$} \\
\hline & & {$[\mathrm{kg}]$} & [Eur] & {$[\mathrm{kg}]$} & [Eur] & {$[\mathrm{kg}]$} & [Eur] & \\
\hline 1 & 2 & 3 & 4 & 5 & 6 & 7 & 8 & 9 \\
\hline 1 & 947.00 & 160.00 & 156.60 & 30.00 & 12.77 & 140.00 & 13.40 & 182.77 \\
\hline 2 & $1,379.00$ & 0.00 & 0.00 & 0.00 & 0.00 & 0.00 & 0.00 & 0.00 \\
\hline 3 & $2,123.00$ & 0.00 & 0.00 & 55.00 & 25.74 & 0.00 & 0.00 & 25.74 \\
\hline 4 & $1,513.00$ & 0.00 & 0.00 & 0.00 & 0.00 & 0.00 & 0.00 & 0.00 \\
\hline 5 & $1,450.00$ & 0.00 & 0.00 & 0.00 & 0.00 & 0.00 & 0.00 & 0.00 \\
\hline 6 & $1,211.00$ & 325.00 & 331.91 & 100.00 & 46.81 & 35.00 & 2.23 & 380.96 \\
\hline 7 & $1,017.00$ & 0.00 & 0.00 & 0.00 & 0.00 & 0.00 & 0.00 & 0.00 \\
\hline 8 & 816.00 & 0.00 & 0.00 & 100.00 & 53.19 & 0.00 & 0.00 & 53.19 \\
\hline 9 & 912.00 & 0.00 & 0.00 & 0.00 & 0.00 & 0.00 & 0.00 & 0.00 \\
\hline 10 & $1,299.00$ & 0.00 & 0.00 & 0.00 & 0.00 & 0.00 & 0.00 & 0.00 \\
\hline
\end{tabular}


End of Table 5

\begin{tabular}{|c|c|c|c|c|c|c|c|c|}
\hline 1 & 2 & 3 & 4 & 5 & 6 & 7 & 8 & 9 \\
\hline 11 & $1,532.00$ & 0.00 & 0.00 & 0.00 & 0.00 & 0.00 & 0.00 & 0.00 \\
\hline 12 & $1,937.00$ & 0.00 & 0.00 & 0.00 & 0.00 & 0.00 & 0.00 & 0.00 \\
\hline 13 & $2,661.00$ & 200.00 & 110.64 & 60.00 & 25.53 & 0.00 & 0.00 & 136.17 \\
\hline 14 & $2,300.00$ & 0.00 & 0.00 & 0.00 & 0.00 & 0.00 & 0.00 & 0.00 \\
\hline 15 & $2,645.00$ & 0.00 & 0.00 & 0.00 & 0.00 & 0.00 & 0.00 & 0.00 \\
\hline 16 & $2,992.00$ & 0.00 & 0.00 & 0.00 & 0.00 & 0.00 & 0.00 & 0.00 \\
\hline 17 & $2,755.00$ & 221.00 & 122.26 & 155.00 & 65.96 & 0.00 & 0.00 & 188.21 \\
\hline 18 & $1,481.00$ & 0.00 & 0.00 & 0.00 & 0.00 & 0.00 & 0.00 & 0.00 \\
\hline 19 & $5,870.00$ & 225.00 & 124.47 & 30.00 & 12.77 & 0.00 & 0.00 & 137.23 \\
\hline 20 & $1,156.00$ & 0.00 & 0.00 & 0.00 & 0.00 & 0.00 & 0.00 & 0.00 \\
\hline 21 & $1,549.00$ & 0.00 & 0.00 & 0.00 & 0.00 & 0.00 & 0.00 & 0.00 \\
\hline 22 & $2,939.00$ & 32.00 & 17.70 & 110.00 & 46.81 & 0.00 & 0.00 & 64.51 \\
\hline 23 & $4,990.00$ & 0.00 & 0.00 & 0.00 & 0.00 & 0.00 & 0.00 & 0.00 \\
\hline 24 & 0.00 & 30.00 & 16.60 & 50.00 & 21.28 & 0.00 & 0.00 & 37.87 \\
\hline TOTAL & $47,474.00$ & $1,193.00$ & 880.17 & 690.00 & 310.85 & 175.00 & 15.64 & $1,206.66$ \\
\hline
\end{tabular}

In order to analyse the way, the manufacture of certain types of products leads to the formation of waste, a hierarchy of the types of products was made according to their weight in the total production of the EE during the 24 months analysed (Table 6). One can observe from the hierarchy presented that a very high weight goes to the products in the Apolo projectors category and in the category for halls, and the lowest ratio goes to the adjustable spot.

Table 6. Hierarchy of product types according to weight in total production of the EE

\begin{tabular}{|c|l|c|c|}
\hline No. & \multicolumn{1}{|c|}{ Categories } & Quantity [pcs] & Total weight [kg] \\
\hline 1 & APOLO_II projectors + halls & $4,766.00$ & $27,083.90$ \\
\hline 2 & SS_Solar + Photon_SPII & $8,566.00$ & $14,156.10$ \\
\hline 3 & Display_Line_III & $3,222.00$ & $7,699.80$ \\
\hline 4 & Proton_projectors & 877.00 & $4,433.80$ \\
\hline 5 & Beacons & $3,989.00$ & $3,217.20$ \\
\hline 6 & Linear_projectors & $2,294.00$ & $3,186.90$ \\
\hline 7 & Ceiling_lights & 795.00 & $2,154.80$ \\
\hline 8 & CISA & $1,317.00$ & $1,056.00$ \\
\hline 9 & Projectors_ASTRO + SATURN & 427.00 & 771.50 \\
\hline 10 & Retrofit. Heliport, Leon & 665.00 & 714.00 \\
\hline 11 & Reloc & 767.00 & 383.50 \\
\hline 12 & Atlas & 214.00 & 272.10 \\
\hline 13 & Lamps_ELM & 113.00 & 90.40 \\
\hline 14 & Rod_LINEA & 182.00 & 72.80 \\
\hline 15 & Adjustable_spots & 78.00 & 21.00 \\
\hline
\end{tabular}




\begin{tabular}{|c|c|c|c|c|c|c|c|c|c|c|c|c|c|c|c|c|c|c|c|c|c|c|c|c|c|c|c|}
\hline \multirow{2}{*}{ से } & छ̇ & $\begin{array}{l}0 \\
0 \\
\dot{0} \\
L \\
2\end{array}$ & & & & & $\begin{array}{l}\text { 로 } \\
\infty \\
\infty \\
\infty\end{array}$ & & & & & & & & $\stackrel{10}{?}$ & & & & 움 & & $\begin{array}{l}\infty \\
\infty \\
1 \\
\infty \\
\infty\end{array}$ & & & $\begin{array}{l}\hat{n} \\
\hat{n} \\
\infty \\
\infty\end{array}$ & & $\begin{array}{l}\stackrel{1}{0} \\
\dot{\infty} \\
\infty \\
\infty\end{array}$ & \\
\hline & $\Xi$ & $\mid \begin{array}{l}0 \\
0 \\
0 \\
0 \\
2\end{array}$ & & & & & $\begin{array}{l}\bar{\sigma} \\
\text { m. }\end{array}$ & & & & & & & & 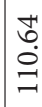 & & & & 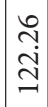 & & 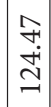 & & & & & $\begin{array}{l}8 \\
\stackrel{0}{0} \\
\dot{0}\end{array}$ & \\
\hline \multirow{2}{*}{ 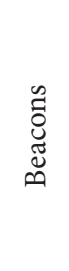 } & छ் & $\mid \begin{array}{c}8 \\
0 \\
0 \\
1 \\
\end{array}$ & $\begin{array}{l}8 \\
\frac{8}{n} \\
\frac{1}{m}\end{array}$ & $\begin{array}{l}8 \\
8 \\
\text { in }\end{array}$ & $\begin{array}{l}8 \\
\infty \\
0 \\
6\end{array}$ & 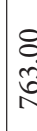 & \begin{tabular}{l}
8 \\
0 \\
0 \\
\hdashline \\
-1
\end{tabular} & $\begin{array}{l}8 \\
\\
\end{array}$ & $\hat{\imath}$ & 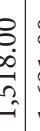 & $\begin{array}{l}8 \\
\dot{a} \\
\dot{a} \\
\underline{0} \\
-1\end{array}$ & $\begin{array}{l}8 \\
0 \\
\infty \\
\infty \\
\infty \\
-1\end{array}$ & $\begin{array}{l}8 \\
0 \\
\infty \\
0 \\
0 \\
\text { n }\end{array}$ & 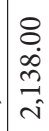 & $\begin{array}{l}8 \\
\text { ¿̂. } \\
\text { Nิ } \\
\text { ป̂ }\end{array}$ & 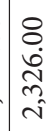 & $\begin{array}{l}8 \\
\infty \\
\infty \\
1 \\
i\end{array}$ & $\begin{array}{l}8 \\
\text { î } \\
\text { d } \\
\text { i }\end{array}$ & 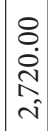 & $\begin{array}{l}8 \\
\infty \\
\infty \\
10 \\
\infty \\
\text { v }\end{array}$ & $\begin{array}{l}8 \\
\dot{n} \\
2 \\
\hat{i}\end{array}$ & $\begin{array}{c}0 \\
0 \\
\dot{n} \\
0 \\
0 \\
m\end{array}$ & $\left|\begin{array}{c}8 \\
8 \\
\dot{j} \\
m \\
m \\
m\end{array}\right|$ & $\begin{array}{c}8 \\
8 \\
\dot{7} \\
\dot{7} \\
\text { m. }\end{array}$ & $\begin{array}{l}8 \\
\\
\dot{0} \\
\infty \\
\infty \\
m\end{array}$ & $\begin{array}{l}8 \\
\check{a} \\
\infty \\
\check{2} \\
\text { n. }\end{array}$ & \\
\hline & $\begin{array}{l}\tilde{U} \\
\stackrel{\Xi}{\Xi}\end{array}$ & $\begin{array}{c}8 \\
0 \\
0 \\
0 \\
=\end{array}$ & 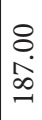 & $\begin{array}{l}8 \\
\dot{\Xi} \\
\stackrel{+}{v}\end{array}$ & $\begin{array}{l}8 \\
\stackrel{\infty}{\circ}\end{array}$ & $\begin{array}{l}8 \\
10 \\
7\end{array}$ & $\begin{array}{l}8 \\
\stackrel{8}{1} \\
\text { mे }\end{array}$ & $\begin{array}{l}8 \\
\text { i }\end{array}$ & $\begin{array}{l}8 \\
j \\
j\end{array}$ & 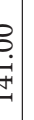 & 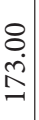 & $\begin{array}{l}8 \\
0 \\
\infty \\
\infty \\
-1\end{array}$ & $\begin{array}{l}8 \\
\stackrel{8}{\circ} \\
-\end{array}$ & $\begin{array}{l}\stackrel{8}{ } \\
\dot{2}\end{array}$ & $\begin{array}{l}8 \\
\dot{+} \\
\infty\end{array}$ & $\begin{array}{l}8 \\
+ \\
\\
-\end{array}$ & $\begin{array}{l}8 \\
\text { g } \\
-\end{array}$ & $\begin{array}{l}\stackrel{8}{0} \\
\\
\end{array}$ & $\begin{array}{l}8 \\
\dot{0} \\
\not{\infty}\end{array}$ & $\begin{array}{l}8 \\
\infty \\
\infty \\
\\
-\end{array}$ & $\begin{array}{l}8 \\
\dot{1} \\
0 \\
-\end{array}$ & 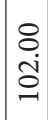 & $\begin{array}{l}8 \\
0 \\
\dot{0} \\
\grave{i}\end{array}$ & $\begin{array}{l}8 \\
0 \\
\dot{9} \\
-1\end{array}$ & 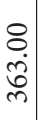 & $\begin{array}{l}8 \\
\dot{0} \\
\infty \\
-1\end{array}$ & $\begin{array}{l}8 \\
\dot{2} \\
2 \\
\text { ஸे }\end{array}$ \\
\hline \multirow{2}{*}{ 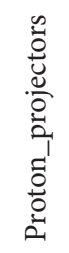 } & 竎 & $\begin{array}{l}8 \\
0 \\
0 \\
0\end{array}$ & $\begin{array}{l}8 \\
\dot{0} \\
\infty\end{array}$ & $\begin{array}{l}8 \\
\dot{0} \\
\text { i }\end{array}$ & $\begin{array}{l}8 \\
\ddot{m} \\
\end{array}$ & $\begin{array}{l}8 \\
8 \\
0 \\
\text { ¿े }\end{array}$ & 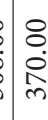 & $\begin{array}{l}8 \\
\text { İ } \\
\text { mे }\end{array}$ & 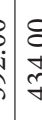 & 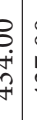 & 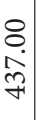 & $\begin{array}{l}8 \\
\stackrel{0}{x} \\
\stackrel{n}{f}\end{array}$ & $\begin{array}{l}8 \\
\text { in } \\
\text { in }\end{array}$ & $\begin{array}{l}8 \\
\dot{0} \\
\infty \\
i n\end{array}$ & $\begin{array}{l}8 \\
0 \\
\text { مें }\end{array}$ & $\begin{array}{l}8 \\
0 \\
0 \\
\text { in }\end{array}$ & $\begin{array}{l}8 \\
8 \\
20 \\
8 \\
0\end{array}$ & $\begin{array}{l}8 \\
\text { : } \\
\text { : }\end{array}$ & $\begin{array}{l}8 \\
\dot{n} \\
\tilde{\sigma}\end{array}$ & $\begin{array}{l}8 \\
\dot{n} \\
\hat{\sigma}\end{array}$ & $\begin{array}{l}8 \\
0 \\
\hat{\Omega} \\
6\end{array}$ & $\begin{array}{l}8 \\
0 \\
\infty \\
0 \\
0\end{array}$ & $\mid \begin{array}{l}8 \\
0 \\
\hat{a} \\
\hat{b}\end{array}$ & $\begin{array}{l}8 \\
\stackrel{+}{\pi} \\
\text { | }\end{array}$ & $\begin{array}{l}8 \\
\stackrel{0}{0} \\
\infty \\
\infty\end{array}$ & \begin{tabular}{l}
8 \\
$\stackrel{\infty}{ }$ \\
\multirow{\infty}{*}{}
\end{tabular} & \\
\hline & $\begin{array}{l}\overline{\tilde{u}} \\
\stackrel{3}{*}\end{array}$ & \begin{tabular}{|l|}
8 \\
$\dot{0}$ \\
$\dot{8}$
\end{tabular} & ஓ & $\begin{array}{l}8 \\
\dot{8} \\
\dot{+}\end{array}$ & $\begin{array}{l}8 \\
\text { m. }\end{array}$ & $\begin{array}{l}8 \\
\text { In } \\
\end{array}$ & $\begin{array}{l}8 \\
\text { î }\end{array}$ & $\begin{array}{l}8 \\
\text { त }\end{array}$ & $\begin{array}{ll} & 8 \\
j & \ddots\end{array}$ & 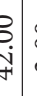 & $\begin{array}{l}\stackrel{\Xi}{ } \\
\dot{m}\end{array}$ & $\begin{array}{l}\stackrel{8}{ } \\
\infty \\
\infty \\
\end{array}$ & $\begin{array}{l}8 \\
\text { f } \\
\text { f }\end{array}$ & $\begin{array}{l}8 \\
\text { in } \\
\text { in }\end{array}$ & 8. & 8 & 8 & 8 & $\begin{array}{l}\stackrel{8}{0} \\
\stackrel{0}{\sim}\end{array}$ & $\stackrel{8}{i}$ & $\begin{array}{l}8 \\
\dot{f} \\
\dot{f}\end{array}$ & $\begin{array}{l}8 \\
\infty \\
\infty\end{array}$ & $\begin{array}{l}8 \\
\dot{0} \\
0\end{array}$ & $\begin{array}{l}8 \\
\dot{f} \\
\dot{f}\end{array}$ & $\begin{array}{l}8 \\
\stackrel{\infty}{ } \\
\infty\end{array}$ & $\begin{array}{l}8 \\
\stackrel{+}{+} \\
\dot{\sim}\end{array}$ & \\
\hline \multirow{2}{*}{ 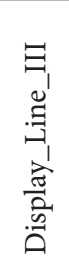 } & छ் & $\begin{array}{c}8 \\
8 \\
10 \\
0 \\
-1\end{array}$ & $\begin{array}{l}8 \\
0 \\
i \\
\infty \\
1 n\end{array}$ & $\begin{array}{l}8 \\
0 \\
\dot{0} \\
8\end{array}$ & $\begin{array}{l}8 \\
\\
\end{array}$ & 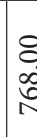 & $\begin{array}{l}8 \\
\text { ஓे }\end{array}$ & $\begin{array}{l}8 \\
\text { ลे } \\
\text { ô }\end{array}$ & 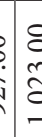 & 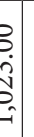 & $\begin{array}{l}8 \\
\dot{0} \\
\dot{a} \\
\dot{0} \\
-1\end{array}$ & $\begin{array}{l}8 \\
0 \\
10 \\
\infty \\
=\end{array}$ & $\begin{array}{l}8 \\
\dot{0} \\
m \\
-\end{array}$ & $\begin{array}{l}8 \\
0 \\
2 \\
\hat{2} \\
-1\end{array}$ & $\begin{array}{l}8 \\
0 \\
\dot{8} \\
0 \\
0 \\
\text { ป̂. }\end{array}$ & $\begin{array}{l}8 \\
\stackrel{8}{0} \\
\hat{0} \\
\hat{i}\end{array}$ & 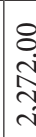 & 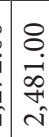 & $\begin{array}{l}8 \\
0 \\
\dot{0} \\
0 \\
\text { i }\end{array}$ & 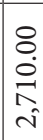 & $\begin{array}{l}8 \\
0 \\
0 \\
\hat{1} \\
\hat{v}\end{array}$ & $\begin{array}{l}8 \\
0 \\
i \infty \\
\infty \\
\hat{1} \\
\hat{1}\end{array}$ & $\mid \begin{array}{c}8 \\
8 \\
0 \\
0 \\
\infty \\
\hat{\sim} \\
\mid\end{array}$ & 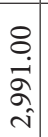 & 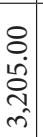 & 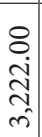 & \\
\hline & $\begin{array}{l}\bar{y} \\
\ddot{y}\end{array}$ & $\begin{array}{l}8 \\
8 \\
10 \\
0 \\
-1\end{array}$ & $\begin{array}{l}8 \\
\frac{8}{2} \\
\frac{1}{7}\end{array}$ & $\begin{array}{l}8 \\
\dot{0} \\
\alpha\end{array}$ & 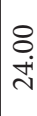 & $\begin{array}{l}8 \\
\text { ț }\end{array}$ & 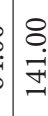 & $\begin{array}{c}8 \\
\infty \\
\infty\end{array}$ & $\begin{array}{l}3 \\
\vdots \\
\vdots\end{array}$ & B. & $\begin{array}{l}8 \\
0 \\
\infty \\
0\end{array}$ & $\begin{array}{l}8 \\
\dot{+} \\
\text { - }\end{array}$ & $\begin{array}{l}8 \\
0 \\
9 \\
\end{array}$ & $\begin{array}{l}8 \\
0 \\
10 \\
0\end{array}$ & 亲 & 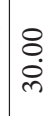 & 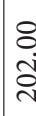 & $\begin{array}{l}\stackrel{8}{\circ} \\
\stackrel{0}{0}\end{array}$ & $\begin{array}{l}8 \\
\dot{0} \\
\ddot{-}\end{array}$ & $\begin{array}{l}8 \\
\dot{8}\end{array}$ & $\begin{array}{l}8 \\
0\end{array}$ & $\begin{array}{l}8 \\
\text { in } \\
\end{array}$ & $\begin{array}{l}8 \\
\dot{1} \\
\infty\end{array}$ & $\begin{array}{l}8 \\
\dot{\vec{I}} \\
\end{array}$ & $\begin{array}{l}\stackrel{8}{ } \\
\dot{J} \\
\vec{\sim}\end{array}$ & $\begin{array}{l}8 \\
\text { ㅁ. } \\
-1\end{array}$ & $\begin{array}{l}8 \\
\text { O. } \\
\text { N } \\
\text { nీ }\end{array}$ \\
\hline \multirow{2}{*}{ 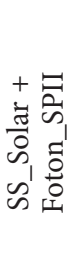 } & छ̇ & $\begin{array}{c}8 \\
\dot{m} \\
\tilde{n}\end{array}$ & $\begin{array}{l}8 \\
8 \\
10\end{array}$ & 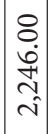 & $\begin{array}{l}8 \\
\infty \\
0 \\
\text { ल } \\
\text { m. }\end{array}$ & $\begin{array}{l}8 \\
m \\
7 \\
m\end{array}$ & 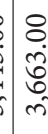 & 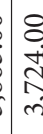 & 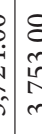 & 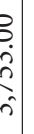 & $\begin{array}{l}8 \\
\dot{0} \\
\grave{\lambda} \\
\dot{n}\end{array}$ & 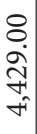 & $\begin{array}{l}8 \\
\text { - } \\
\text { î } \\
\text { in }\end{array}$ & 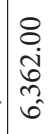 & $\begin{array}{l}8 \\
\text { ப் } \\
\text { fิ } \\
6\end{array}$ & $\begin{array}{l}8 \\
8 \\
6 \\
10 \\
6 \\
6\end{array}$ & \& & $\begin{array}{c}8 \\
8 \\
0 \\
\\
0\end{array}$ & $\begin{array}{l}8 \\
0 \\
10 \\
\infty \\
0 \\
0\end{array}$ & $\begin{array}{l}8 \\
\text { ڤે } \\
\hat{\alpha} \\
\hat{\sigma}\end{array}$ & $\begin{array}{l}8 \\
\dot{0} \\
\infty \\
\sim \\
\sim \\
n\end{array}$ & 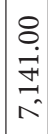 & $\mid \begin{array}{c}8 \\
8 \\
2 \\
10 \\
+ \\
n \\
\end{array}$ & $\begin{array}{l}8 \\
\stackrel{1}{+} \\
\dot{0} \\
\stackrel{1}{N}\end{array}$ & $\begin{array}{c}8 \\
\dot{0} \\
\hat{0} \\
\infty \\
\infty\end{array}$ & $\begin{array}{l}8 \\
\circ \\
\dot{0} \\
1 \\
\infty \\
\infty\end{array}$ & \\
\hline & $\begin{array}{l}\bar{y} \\
ٌ \\
\ddot{y}\end{array}$ & $\begin{array}{c}8 \\
\dot{m} \\
\tilde{m}\end{array}$ & $\begin{array}{l}8 \\
\stackrel{8}{+} \\
\stackrel{+}{+}\end{array}$ & $\begin{array}{l}8 \\
0 \\
\infty \\
1 \\
-1\end{array}$ & $\begin{array}{l}8 \\
i \\
\infty \\
\infty \\
\infty\end{array}$ & $\begin{array}{l}8 \\
\text { in } \\
m\end{array}$ & 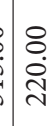 & $\frac{8}{6}$ & $\dot{b}$ & Ș. & $\begin{array}{l}8 \\
\vdots \\
\dot{+}\end{array}$ & $\begin{array}{l}8 \\
0 \\
\dot{0} \\
\delta \\
0\end{array}$ & $\begin{array}{l}8 \\
\stackrel{1}{1} \\
\text { ஸे } \\
\infty\end{array}$ & $\begin{array}{l}0 \\
0 \\
0 \\
-1\end{array}$ & $\begin{array}{l}8 \\
\text { ภું }\end{array}$ & $\frac{8}{\mathrm{~m}}$ & $\begin{array}{l}8 \\
\text { in } \\
\text { n. }\end{array}$ & $\begin{array}{l}8 \\
\stackrel{0}{\sim} \\
\sim\end{array}$ & $\begin{array}{l}8 \\
10 \\
10 \\
1\end{array}$ & $\begin{array}{l}8 \\
\infty \\
\infty \\
m\end{array}$ & 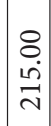 & $\begin{array}{l}8 \\
\dot{m}\end{array}$ & $\mid \begin{array}{c}8 \\
\infty \\
\infty \\
m\end{array}$ & $\begin{array}{l}8 \\
8 \\
\dot{9} \\
-1\end{array}$ & $\begin{array}{l}8 \\
\stackrel{+}{ } \\
\text { }\end{array}$ & $\begin{array}{l}8 \\
0 \\
\text { రై } \\
\text {. }\end{array}$ & $\begin{array}{l}8 \\
0 \\
0 \\
0 \\
10 \\
\infty\end{array}$ \\
\hline \multirow{2}{*}{ 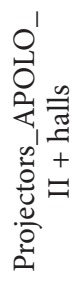 } & छ் & $\begin{array}{c}8 \\
\dot{0} \\
\infty\end{array}$ & $\frac{8}{\bar{g}}$ & $\begin{array}{l}8 \\
\text { o } \\
\dot{+} \\
\text { లn }\end{array}$ & $\begin{array}{l}8 \\
\text { ते } \\
\text { î }\end{array}$ & $\begin{array}{l}8 \\
2 \\
\end{array}$ & $\begin{array}{l}8 \\
0 \\
\stackrel{1}{1} \\
\infty\end{array}$ & $\begin{array}{l}8 \\
\dot{0} \\
\infty \\
0 \\
0\end{array}$ & 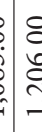 & 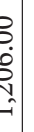 & 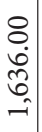 & $\begin{array}{l}8 \\
8 \\
\dot{0} \\
\infty \\
\infty \\
-1\end{array}$ & $\begin{array}{l}8 \\
0 \\
2 \\
\sigma \\
-\end{array}$ & $\begin{array}{l}8 \\
0 \\
\infty \\
0 \\
0 \\
i\end{array}$ & $\begin{array}{l}8 \\
\text { ¿̂. } \\
\text { Nิ } \\
\text { ป̂. }\end{array}$ & 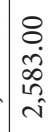 & $\begin{array}{l}8 \\
0 \\
10 \\
0 \\
0 \\
i\end{array}$ & $\begin{array}{l}8 \\
\dot{m} \\
m \\
m\end{array}$ & 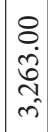 & $\begin{array}{l}8 \\
\dot{m} \\
\ddot{m} \\
\dot{f} \\
\dot{m}\end{array}$ & $\begin{array}{l}8 \\
\dot{a} \\
\dot{+} \\
\dot{m}\end{array}$ & $\begin{array}{c}0 \\
8 \\
+\dot{+} \\
0 \\
0 \\
+ \\
+\end{array}$ & 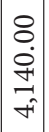 & 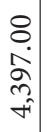 & 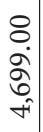 & $\begin{array}{l}8 \\
8 \\
\dot{0} \\
\stackrel{0}{*} \\
\dot{\nabla}\end{array}$ & \\
\hline & $\begin{array}{l}\bar{y} \\
\ddot{z}\end{array}$ & $\begin{array}{l}8 \\
\dot{0} \\
\infty\end{array}$ & 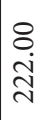 & $\begin{array}{l}8 \\
\dot{0} \\
\text { ñ }\end{array}$ & $\begin{array}{l}8 \\
0 \\
10 \\
1\end{array}$ & $\begin{array}{l}8 \\
8 \\
7\end{array}$ & 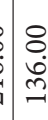 & $\begin{array}{l}8 \\
\infty \\
\infty\end{array}$ & $\begin{array}{l}b_{b} \\
\dot{b} \\
\dot{u}\end{array}$ & 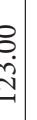 & $\begin{array}{l}8 \\
\stackrel{0}{ } \\
\stackrel{+}{ }\end{array}$ & $\begin{array}{l}8 \\
\dot{0} \\
\stackrel{-}{-}\end{array}$ & $\begin{array}{l}8 \\
8 \\
10 \\
1\end{array}$ & $\begin{array}{l}8 \\
\text { in }\end{array}$ & $\begin{array}{l}8 \\
0 \\
\Omega \\
\end{array}$ & $\begin{array}{l}8 \\
0 \\
\dot{0} \\
n\end{array}$ & 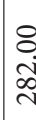 & $\begin{array}{l}8 \\
0 \\
0 \\
\hat{0}\end{array}$ & $\begin{array}{l}8 \\
0 \\
\infty \\
-1 \\
-1\end{array}$ & $\begin{array}{l}\stackrel{8}{0} \\
\stackrel{1}{1} \\
\end{array}$ & $\begin{array}{l}8 \\
0 \\
\dot{0} \\
\dot{n}\end{array}$ & $\begin{array}{l}8 \\
0 \\
\\
-\end{array}$ & $\begin{array}{l}8 \\
8 \\
6 \\
\text { in }\end{array}$ & \begin{tabular}{l}
8 \\
\multirow{2}{0}{} \\
$i$
\end{tabular} & $\begin{array}{c}8 \\
\text {. } \\
\text { ¿े } \\
\text { }\end{array}$ & $\begin{array}{l}8 \\
\text { î. }\end{array}$ & 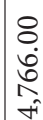 \\
\hline \multicolumn{2}{|c|}{$\begin{array}{l}\text { 㤩 } \\
\text { 艺 }\end{array}$} & -1 & $\sim$ & $n$ & 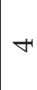 & ᄂ & 0 & $\Lambda$ & $\infty$ & $\infty$ & $a$ & 으 & $\exists$ & $\simeq$ & $\stackrel{m}{-1}$ & \pm & 는 & $\because$ & 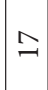 & $\stackrel{\infty}{-1}$ & $\beth$ & ¿ & $\vec{\sim}$ & ป & $\tilde{\sim}$ & $\stackrel{\leftrightarrow}{\sim}$ & 苟 \\
\hline
\end{tabular}


In order to determine the dependence between product categories and resulting waste, only the first five product categories were considered, as an example, Table 7 presents the monthly (cumulative) quantities (number of items) of the five main categories. The recovery of the $A l w$ is not made monthly but irregularly, at an interval of several months. Thus, the quantity of waste recovered reflects the activity of the production for several months, more precisely, over the entire time interval since the previous recovery of the waste. It is precisely this irregular recovery of waste that calls for an analysis of the dependencies between product categories and waste, using aggregated data (Table 8).

Table 8. Data used for dependency analysis

\begin{tabular}{|c|c|c|c|c|c|c|}
\hline \multirow{2}{*}{ No. } & \multicolumn{5}{|c|}{ Production of equipment by categories } & \multirow{2}{*}{$\begin{array}{c}\text { Alw resulted } \\
\text { and valorized } \\
\text { [eur] }\end{array}$} \\
\hline & $\begin{array}{c}\mathrm{C} 1 \\
{[\mathrm{pcs}]}\end{array}$ & $\begin{array}{c}\mathrm{C} 2 \\
{[\mathrm{pcs}]}\end{array}$ & $\begin{array}{c}\mathrm{C} 3 \\
{[\mathrm{pcs}]}\end{array}$ & $\begin{array}{c}\mathrm{C} 4 \\
{[\mathrm{pcs}]}\end{array}$ & $\begin{array}{c}\mathrm{C} 5 \\
{[\mathrm{pcs}]}\end{array}$ & \\
\hline 1 & 89.00 & 33.00 & 165.00 & 60.00 & 128.00 & 156.60 \\
\hline 2 & 875.00 & $3,663.00$ & 909.00 & 370.00 & $1,105.00$ & 488.51 \\
\hline 3 & $2,227.00$ & $6,425.00$ & $2,040.00$ & 596.00 & $2,222.00$ & 599.15 \\
\hline 4 & $3,263.00$ & $6,885.00$ & $2,620.00$ & 633.00 & $2,720.00$ & 721.40 \\
\hline 5 & $3,949.00$ & $7,138.00$ & $2,710.00$ & 679.00 & $2,993.00$ & 845.87 \\
\hline 6 & $4,397.00$ & $7,604.00$ & $2,991.00$ & 741.00 & $3,441.00$ & 863.57 \\
\hline 7 & $4,766.00$ & $8,566.00$ & $3,222.00$ & 877.00 & $3,989.00$ & 880.17 \\
\hline
\end{tabular}

Determining the dependency relationship between a particular type of waste and the categories of manufactured products is of particular importance for several reasons, of which the most important are:

- estimating the volume of waste produced according to the planned volume of production by product categories;

- analysis of the production technologies to identify which product category generates a large volume of waste in manufacturing. Once the category has been identified, it is necessary to review the technology of the product category so that, by improved technology, the loss of raw material in waste in the form of cuttings, scrapings, or other debris from the factory will be reduced.

A model for determining the dependence between the $A l w$ and the five main product categories will be presented: C1: APOLO II projectors + halls; C2: SS Solar + Photon SP II; C3: Display Line III; C4: Proton projectors; C5: Mark. Essentially, the dependency determination consists in determining the coefficients $a_{11}, a_{12}, \ldots, a_{15}$ with the meanings presented previously in the paper, so that by applying them to the volume of production (monthly or cumulative over a longer period) of each category $p_{1}, p_{2}, \ldots, p_{5}$ leads to a result as close to the value of the waste redeemed for that period as possible. From a mathematical point of view, things can be expressed in this way:

$$
a_{11} p_{1}+a_{12} p_{2}+a_{13} p_{3}+a_{14} p_{4}+a_{15} p_{5}=I_{1} \pm \varepsilon
$$

where, $\varepsilon$ - the deviation (difference) between the real value of the waste $I_{1}$ and the value 
calculated based on dependency coefficients. The value $\varepsilon$ should be as small as possible for each time interval of the equation. For the situation described in Table 8, containing cumulative values for different periods from 1 to 24 months, the system can be written:

$89.00 \times a_{11}+33.00 \times a_{12}+165.00 \times a_{13}+60.00 \times a_{14}+128.00 \times a_{15}-156.60=\varepsilon_{1} ;$

$875.00 \times a_{11}+3,663.00 \times a_{12}+909.00 \times a_{13}+370.00 \times a_{14}+1,105.00 \times a_{15}-488.51=\varepsilon_{2} ;$

$2,227.00 \times a_{11}+6,425.00 \times a_{12}+2,040.00 \times a_{13}+596.00 \times a_{14}+2,222.00 \times a_{15}-599.15=\varepsilon_{3} ;$

$3,263.00 \times a_{11}+6,885.00 \times a_{12}+2,620.00 \times a_{13}+633.00 \times a_{14}+2,720.00 \times a_{15}-721.40=\varepsilon_{4} ;$

$3,949.00 \times a_{11}+7,138.00 \times a_{12}+2,710.00 \times a_{13}+679.00 \times a_{14}+2,993.00 \times a_{15}-845.87=\varepsilon_{5} ;$

$4,397.00 \times a_{11}+7,604.00 \times a_{12}+2,991.00 \times a_{13}+741.00 \times a_{14}+344.00 \times a_{15}-1863.57=\varepsilon_{6} ;$

$4,766.00 \times a_{11}+8,566.00 \times a_{12}+3,222.00 \times a_{13}+877.00 \times a_{14}+3,989.00 \times a_{15}-880.17=\varepsilon_{7}$.

It can be seen that the system is not an ordinary algebraic one, in that the number of equations is not equal to the number of unknowns. Among the unknowns of the system are even the coefficients $a_{1 k}, k=1, \ldots 5$, which define the dependence or more precisely express the participation of a product of category $k$, in the production of Alw. Such a system is solved by additionally attaching the condition:

$$
\sum_{j=1}^{7} \varepsilon_{j}^{2}=\min .
$$

The problem is essentially a problem of optimization or finding of an extreme (the minimum of the squares of deviations) from which also results in the set of values $a_{1 k}, k=1 \ldots 5$. To solve the problem, the following function is built:

$$
F_{1}=\varepsilon_{1}^{2}+\varepsilon_{2}^{2}+\varepsilon_{3}^{2}+\ldots+\varepsilon_{7}^{2},
$$

where, then the values $\varepsilon_{1}, \varepsilon_{2}, \ldots, \varepsilon_{7}$ are replaced by $a_{11}, a_{12}, \ldots, a_{15}$, using the relations from the previous system. Thus, the function $F_{1}$ will be expressed according to the variables $a_{11}$, $a_{12}, \ldots, a_{15}$ which also play the role of unknowns.

$$
F_{1}=F_{1}\left(a_{11}, a_{12}, \ldots, a_{15}\right) .
$$

The minimum of this function will be ensured by the conditions: $\frac{\partial F_{1}}{\partial a_{11}}=0 ; \frac{\partial F_{1}}{\partial a_{12}}=0$; $\frac{\partial F_{1}}{\partial a_{13}}=0 ; \frac{\partial F_{1}}{\partial a_{14}}=0 ; \frac{\partial F_{1}}{\partial a_{15}}=0$, conditions that form a system of 5 equations from whose solution result even the five unknowns $a_{11}, a_{12}, \ldots, a_{15}$. From a practical viewpoint, using the optimization module "Solver" is advantageous because it is no longer necessary to derive the function to be minimized or to solve the system of equations for partial derivatives (Frontline Solvers, n.d.).

The information from Table 8 is first entered into a worksheet in Excel, and then initialized randomly taken values for unknowns are given. It was taken randomly 0.20 the value for each unknowns (these values will be changed automatically by the program, but in this first stage, some values must be entered in order to build the mathematical model). Using the initial values given to the unknowns $a_{11}, a_{12}, \ldots, a_{15}$ values of the formed Alw will be 
calculated, being calculated 7 values, one for each series of information. The calculated values of the resulting waste quantities will be obtained later, the results being different from the actual values (made) for Alw. The ratios of the seven categories express the fact that the seven rows of information have different "weights", as some represent cumulative values over shorter periods (the first series), while others represent cumulative values over longer periods (the last series). Calling the Solver Solution Module will open a window, which will complete the following (Figure 2).

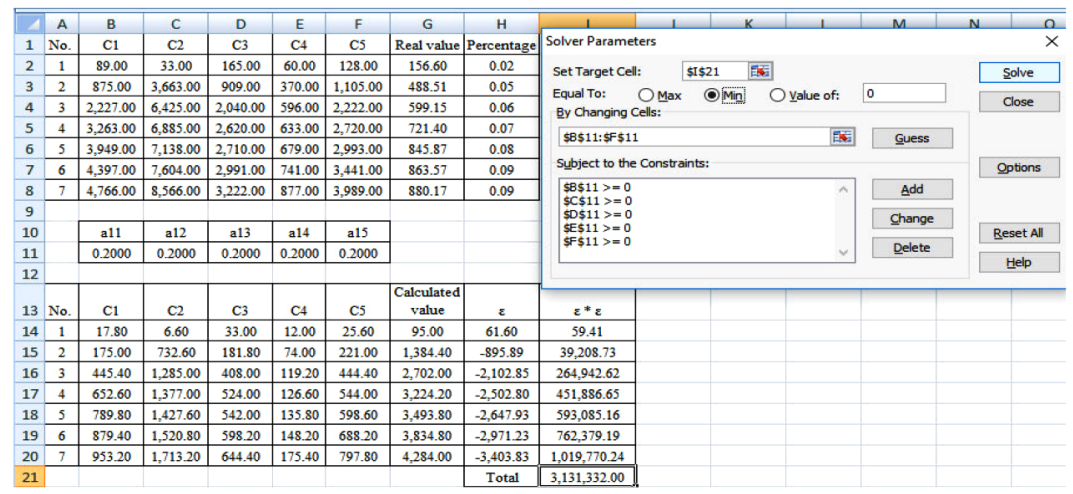

Figure 2. Spreadsheet for determining unknown parameters using the Solver module

In the calculation, cell I21 contains the sum of the squares of the errors that is the function for which a minimum is searched. Solver values for unknowns are: $a_{11}=0.0193, a_{12}=$ 0.0756, $a_{13}=0.0000, a_{14}=0.2355, a_{15}=0.0000$, having the following meaning:

- the biggest contribution to the production of $A l w$ belongs to the products from category 4 (Proton projectors) followed by those of category 2 and 1 respectively;

- the categories 3 and 5 do not influence the production of Alw.

The value $I_{1}$ estimated to be collected from the recovery of type 1 waste (aluminium) can be calculated with the relation:

$$
I_{1}=0.0193 p_{1}+0.0756 p_{2}+0.0000 p_{3}+0.2355 p_{4}+0.0000 p_{5},
$$

where the categories $p_{1}, p_{2}, \ldots, p_{5}$ are the quantities of products in the production plan, for each product category.

As a proof of the dependency relation, the relation was applied to the volumes of production performed at the level of each category (Table 8), and the results calculated with the established dependency relation, were compared with the actual ones, those actually achieved during 2017-2018 (Figure 3).

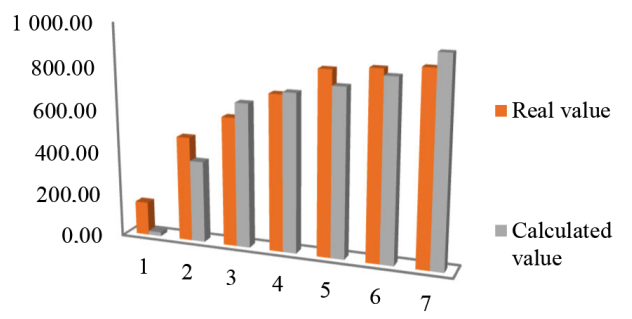

Figure 3. Real value of the volume of produced Alw, versus calculated value 
It is observed that the results are extremely close, the biggest difference between results is found at the level of the first stage of recovery of the Alw that took place in January 2017. At the same time, the real value of the $A l w$ is much greater compared to the calculated value, because the calculated value was based only on the products manufactured in January 2017, while the real $A l w$ was also generated by the production for the last months of 2016 that was not taken into account.

\section{Discussion}

According to the mathematical model for determining the dependence between Alw and the volume of production on each category of products, other types of dependencies can be determined. Thus, a function $f_{2}$ can be determined for estimating the value $I_{2}$ of the scrap waste according to the production by product categories:

$$
I_{2}=f_{2}\left(p_{1}, p_{2}, p_{3} \ldots p_{n}\right)=a_{21} p_{1}+a_{22} p_{2}+a_{23} p_{3}+\ldots+a_{2 n} p_{n} .
$$

Also, a function $f_{3}$ can be determined for estimating the value $I_{3}$ of the scrap iron according to the production by product categories:

$$
I_{3}=f_{3}\left(p_{1}, p_{2}, p_{3} \ldots p_{n}\right)=a_{31} p_{1}+a_{32} p_{2}+a_{33} p_{3}+\ldots+a_{3 n} p_{n} .
$$

It is possible in this way, to have an overview of the EC expressed through a relationship such as:

$$
C=\left(\begin{array}{lllll}
p_{1} & p_{2} & \ldots & p_{n} & 1
\end{array}\right)\left[\begin{array}{ccc}
w_{1} & 0 & 0 \\
w_{2} & 0 & 0 \\
\ldots & \ldots & \ldots \\
w_{n} & 0 & 0 \\
0 & w_{b} & w_{a}
\end{array}\right]\left[\begin{array}{c}
c^{\text {prod }} \\
c^{\text {bat }} \\
c^{\text {pack }}
\end{array}\right]-[1,1,1]\left[\begin{array}{cccc}
a_{11} & a_{12} & \ldots & a_{1 n} \\
a_{21} & a_{22} & \ldots & a_{2 n} \\
a_{31} & a_{32} & \ldots & a_{3 n}
\end{array}\right]\left[\begin{array}{c} 
\\
p_{1} \\
p_{2} \\
\ldots \\
p_{n}
\end{array}\right] .
$$

The relationship is also useful for analysing how a product in category $k$ affects EC. For this purpose, the partial derivatives are calculated, that is, the function $C$ is derived one by one, with respect to each variable $p_{k}$, all the other elements in the composition of the expression $C$ being known constants. Such a derivative express what would happen to the EC if production with another product in category $k$ were to increase:

$$
\frac{\partial C}{\partial p_{k}}, \text { where } k=1 \ldots n .
$$

By comparing the values of the derivatives, one can identify those product categories that most affect the EC. A large derivative expresses a strong contribution to the EC of a product of category $k$ in relation to which the derivation was made. In another aspect, the presence of large value in the matrix of elements $a_{J K}$ indicates that the manufacture of a product of category $k$ produces a significant contribution to the category $J$ of waste. In such a situation, a review of the technology used to manufacture products of category $K$ is required, at 
that point of manufacture where the raw material $J$ is used, so that it is not unduly lost in a category $J$ waste.

\section{Conclusions}

Determining the EC in the electrical equipment industry, through the use of environmental accounting as a strategic instrument to control the EE allows the identification and implementation of solutions for the most environmentally friendly production. At the same time, environmental accounting contributes to the formation of investment plans regarding ecological technologies that aim to design and market products with the least environmental impact while minimizing the total EC per EE. By integrating the proposed mathematical model, it can be considered that it is possible to adapt, extend and implement the EE from different fields of activity, which put on the market products that have a significant impact on the environment. The implementation of such a mathematical model can be limited by the determination of the total EC for EE, because it is a complex process integrated in the environmental management of the entities, which depends simultaneously on the specificity of the industry, on the size of EE, on the production flow, and on the relationships with third parties.

The identification of the products with an imprint on the environment and the study of the dependence between the resulting waste and the volume of production by categories leads to the development of a sustainable environmental accounting system within the industrial entities, which will provide support for the outline of managerial strategies for the revision of the production technologies, to optimize products and reduce the amount of waste generated. As future prospects for the development of the present research topic, it could be considered useful to develop an econometric model that quantifies and highlights the technological impact on the reduction of EC, necessary to improve the efficient management of EC.

\section{Funding}

This research received no external funding.

\section{Author contributions}

All the authors contributed equally to the elaboration of this research.

\section{Disclosure statement}

The authors declare no conflict of interest.

\section{References}

Andersen, M. S. (2007). An introductory note on the environmental economics of the circular economy. Sustainability Science, 2(1), 133-140. https://doi.org/10.1007/s11625-006-0013-6 
Armas-Cruz, Y., Gil-Soto, E., \& Oreja-Rodríguez, J. R. (2017). Environmental management in SMEs: Organizational and sectoral determinants in the context of an Outermost European Region. Journal of Business Economics and Management, 18(5), 935-953. https://doi.org/10.3846/16111699.2017.1373375

Baldarelli, M. G., Del Baldo, M., \& Nesheva-Kiosseva, N. (2017). Environmental Accounting and Reporting. CSR, Sustainability, Ethics \& Governance. Springer. https://doi.org/10.1007/978-3-319-50918-1

Baumann, H., \& Cowell, S. J. (1999). An evaluative framework for conceptual and analytical approaches used in environmental management. Greener Management International, 26, 109-122.

Bebbington, J., \& Larrinaga, C. (2014). Accounting and sustainable development: An exploration. Accounting, Organizations and Society, 39(6), 395-413. https://doi.org/10.1016/j.aos.2014.01.003

Burritt, R. L., Herzig, C., Schaltegger, S., \& Viere, T. (2019). Diffusion of environmental management accounting for cleaner production: Evidence from some case studies. Journal of Cleaner Production, 224, 479-491. https://doi.org/10.1016/j.jclepro.2019.03.227

Ciambrone, D. F. (2018). Environmental life cycle analysis. CRC Press. https://doi.org/10.1201/9780203757031

Christ, K. L., \& Burritt, R. L. (2013). Environmental management accounting: the significance of contingent variables for adoption. Journal of Cleaner Production, 41, 163-173. https://doi.org/10.1016/j.jclepro.2012.10.007

Cucchiella, F., D’Adamo, I., \& Gastaldi, M. (2014). Sustainable management of waste-to-energy facilities. Renewable and Sustainable Energy Reviews, 33, 719-728. https://doi.org/10.1016/j.rser.2014.02.015

da Cruz, N. F., Ferreira, S., Cabral, M., Simões, P., \& Marques, R. C. (2014). Packaging waste recycling in Europe: is the industry paying for it?. Waste Management, 34(2), 298-308. https://doi.org/10.1016/j.wasman.2013.10.035

de Oliveira Neto, G. C., Vendrametto, O., Naas, I. A., Palmeri, N. L., \& Lucato, W. C. (2016). Environmental impact reduction as a result of cleaner production implementation: a case study in the truck industry. Journal of Cleaner Production, 129, 681-692. https://doi.org/10.1016/j.jclepro.2016.03.086

European Commission. (2001). Commission Recommendation of 30 May 2001 on the recognition, measurement and disclosure of environmental issues in the annual accounts and annual reports of EU companies (2001/453/EC). https://eur-lex.europa.eu/LexUriServ/LexUriServ.do?uri=OJ:L:2001:156 :0033:0042:EN:PDF

Everett, T., Ishwaran, M., Ansaloni, G. P., \& Rubin, A. (2010). Economic growth and the environment. https://assets.publishing.service.gov.uk/government/uploads/system/uploads/attachment_data/ file/69195/pb13390-economic-growth-100305.pdf

Ferreira, S., Cabral, M., da Cruz, N. F., Simões, P., \& Marques, R. C. (2014). Life cycle assessment of a packaging waste recycling system in Portugal. Waste Management, 34(9), 1725-1735. https://doi. org/10.1016/j.wasman.2014.05.007

Frontline Solvers. (n.d.). Excel solver help. http://www.solver.com/excel-solver-help

Fuzi, N. M., Habidin, N. F., Janudin, S. E., \& Ong, S. Y. Y. (2019). Environmental management accounting practices, environmental management system and environmental performance for the Malaysian manufacturing industry. International Journal of Business Excellence, 18(1), 120-136. https://doi.org/10.1504/IJBEX.2019.099452

Gala, A. B., Raugei, M., Ripa, M., \& Ulgiati, S. (2015). Dealing with waste products and flows in life cycle assessment and emergy accounting: Methodological overview and synergies. Ecological Modelling, 315, 69-76. https://doi.org/10.1016/j.ecolmodel.2015.03.004

Gale, R. (2006). Environmental management accounting as a reflexive modernization strategy in cleaner production. Journal of Cleaner Production, 14(14), 1228-1236.

https://doi.org/10.1016/j.jclepro.2005.08.008 
Gerasimova, L., \& Silka, D. (2019). Concept of costs management with environmental protection functions. E3S Web of Conferences, 110, 02014. https://doi.org/10.1051/e3sconf/201911002014

Ghaemmaghami, K., Zamani, M., \& Shafiei, H. (2018). Investigating environmental accounting and its role in reducing environmental costs (case study: Iran Noubaft textile company). Journal of Accounting, Finance and Auditing Studies, 4(4), 185-202. https://doi.org/10.32602/jafas.2018.012

Gray, R. (2010). Is accounting for sustainability actually accounting for sustainability... and how would we know? An exploration of narratives of organisations and the planet. Accounting, Organizations and Society, 35(1), 47-62. https://doi.org/10.1016/j.aos.2009.04.006

Grubb, M., Koch, M., Thomson, K., Sullivan, F., \& Munson, A. (2019). The 'Earth Summit' agreements: A guide and assessment. An analysis of the Rio'92 UN Conference on Environment and Development (Vol. 9). Routledge. https://doi.org/10.4324/9780429273964

Harris, J. M., \& Codur, A. M. (2004). Macroeconomics and the environment. Global Development and Environment Institute, Universidad de Tufts. http://www.masterhdfs.org/masterHDFS/wp-content/ uploads/2014/05/Microeconomics_and_the_Environment.pdf

Henri, J. F., Boiral, O., \& Roy, M. J. (2016). Strategic cost management and performance: The case of environmental costs. The British Accounting Review, 48(2), 269-282.

https://doi.org/10.1016/j.bar.2015.01.001

Hottenrott, H., Rexhäuser, S., \& Veugelers, R. (2016). Organisational change and the productivity effects of green technology adoption. Resource and Energy Economics, 43, 172-194.

https://doi.org/10.1016/j.reseneeco.2016.01.004

Hroncová Vicianová, J., Jadudová, J., Hronec, M., \& Rolíková, S. (2017). Developing eco-innovation in business practice in Slovakia. Journal of Business Economics and Management, 18(5), 1042-1061. https://doi.org/10.3846/16111699.2017.1381146

Iriarte, A., Gabarrell, X., \& Rieradevall, J. (2009). LCA of selective waste collection systems in dense urban areas. Waste Management, 29(2), 903-914. https://doi.org/10.1016/j.wasman.2008.06.002

Ionescu, C. A. (2017). Integrating the environmental accounting on the information system of the economic entities. Hyperion Economic Journal, 5(2), 42-48.

Jasch, C. (2009). Environmental and material flow cost accounting: principles and procedures (Vol. 25). Springer Science \& Business Media B.V.

Jasch, C. (2003). The use of Environmental Management Accounting (EMA) for identifying environmental costs. Journal of Cleaner Production, 11(6), 667-676. https://doi.org/10.1016/S0959-6526(02)00107-5

Kusch-Brandt, S. (2018). E-waste (waste electrical and electronic equipment) - The other side of rapid technological changes. http://www.sigrid-kusch.de/mediapool/55/553823/data/SciencePolicy_Brief_ WEEE_CE_2018_Kusch.pdf

Lauridsen, E. H., \& Jørgensen, U. (2010). Sustainable transition of electronic products through waste policy. Research Policy, 39(4), 486-494. https://doi.org/10.1016/j.respol.2010.01.021

Lee, K. H. (2011). Motivations, barriers, and incentives for adopting environmental management (cost) accounting and related guidelines: a study of the republic of Korea. Corporate Social Responsibility and Environmental Management, 18(1), 39-49. https://doi.org/10.1002/csr.239

Mazahrih, B. (2019). Integration of environmental costs into accounting information system. Academy of Accounting and Financial Studies Journal, 23(4). https://www.abacademies.org/articles/Integration-of-Environmental-Costs-into-Accounting-Information-System-1528-2635-23-4-446.pdf

Mazahir, S., Verter, V., Boyaci, T., \& Van Wassenhove, L. N. (2019). Did Europe move in the right direction on E-waste legislation?. Production and Operations Management, 28(1), 121-139.

https://doi.org/10.1111/poms.12894 
Nistor, C. S., Deaconu, A., \& Mare, C. (2015). Influence of environmental factors on the evolution of Romanian public accounting. Journal of Business Economics and Management, 16(6), 1154-1169. https://doi.org/10.3846/16111699.2013.804872

Potocan, V., Nedelko, Z., Peleckienè, V., \& Peleckis, K. (2016). Values, environmental concern and economic concern as predictors of enterprise environmental responsiveness. Journal of Business Economics and Management, 17(5), 685-700. https://doi.org/10.3846/16111699.2016.1202315

Rakos, I. S., \& Antohe, A. (2014). Environmental cost - an environment management accounting component. International Journal of Academic Research in Accounting, Finance and Management Sciences, 4(4), 166-175. https://doi.org/10.6007/IJARAFMS/v4-i4/1302

Rigamonti, L., Grosso, M., \& Giugliano, M. (2009). Life cycle assessment for optimising the level of separated collection in integrated MSW management systems. Waste Management, 29(2), 934-944. https://doi.org/10.1016/j.wasman.2008.06.005

Sauvé, S., Bernard, S., \& Sloan, P. (2016). Environmental sciences, sustainable development and circular economy: Alternative concepts for trans-disciplinary research. Environmental Development, 17, 48-56. https://doi.org/10.1016/j.envdev.2015.09.002

Schaltegger, S., \& Burritt, R. (2017). Contemporary environmental accounting: issues, concepts and practice. Routledge. https://doi.org/10.4324/9781351282529

Smaliukienè, R. (2007). Stakeholders' impact on the environmental responsibility: Model design and testing. Journal of Business Economics and Management, 8(3), 213-223. https://doi.org/10.3846/16111699.2007.9636171

Sorina-Geanina, M. S., Cornelia, B. S. N., Nicoleta, I. E., \& Ileana-Sorina, B. R. (2012). Coverage of environmental information in annual financial statements in a responsible manner. Procedia - Social and Behavioral Sciences, 62, 526-530. https://doi.org/10.1016/j.sbspro.2012.09.086

Topor, D. I., Căpuşneanu, S., Constantin (Oprea), D. M., Barbu, C. M., \& Rakos (Boca), I. S. (2017). $\mathrm{ABB}-\mathrm{ABC}-\mathrm{ABE}-\mathrm{ABM}$ approach for implementation in the economic entities from energy industry. Business and Management Horizons, 5(2), 36-48. https://doi.org/10.5296/bmh.v5i2.12169

Tsui, C. S. K. (2014). A literature review on environmental management accounting (EMA) adoption. Web Journal of Chinese Management Review, 17(3), 1-19.

United Nations Conference on Trade and Development. (2001). Environment. https://unctad.org/en/ Docs/psiteiitd23.en.pdf

United Nations. (1997). Glossary of environment statistics (Studies in Methods, Series F, No. 67). New York. https://unstats.un.org/unsd/publication/SeriesF/SeriesF_67E.pdf

U.S. Environmental Protection Agency. (2014). An introduction to environmental accounting as a business management tool: Environmental as a business management tool: Key concepts and terms. https://www.epa.gov/sites/production/files/2014-01/documents/busmgt.pdf

U.S. Environmental Protection Agency. (1995). Valuing potential environmental liabilities for managerial decision-making: A review of available techniques. http://www.epa.gov

Zou, T., Zeng, H., Zhou, Z., \& Xiao, X. (2019). A three-dimensional model featuring material flow, value flow and organization for environmental management accounting. Journal of Cleaner Production, 228, 619-633. https://doi.org/10.1016/j.jclepro.2019.04.309 